\title{
INTERNET SEARCH TRAFFIC AND ITS INFLUENCE ON LIQUIDITY AND RETURNS OF INDONESIA STOCKS: AN EMPIRICAL STUDY
}

\author{
Berto Usman \\ Department of Management, Faculty of Economics and Business \\ University of Bengkulu \\ (berto_usman@yahoo.co.id) \\ Eduardus Tandelilin \\ Department of Management, Faculty of Economics and Business \\ Universitas Gadjah Mada \\ (tandelilin@yahoo.com)
}

\begin{abstract}
The development of advanced information technology has become a standard in the process of improving corporate value. This is seen through the high level of investors' awareness of the brand and information that company holds (Da, Engleberg, and Gao, 2011; Bank, Larch, and George, 2011; Joseph, Wintoki, and Zhang, 2011). Among the information providers, internet plays an important role not only in accessing information, but also as a medium that can be applied to publish a wide range of financial reports or news to attract investors. This study aims to examine the effect of investors' attention towards returns, liquidity and volatility of stock returns. The results indicate that investors' attention which is represented by Google Insight contributes positively and significantly to the explanation of returns, liquidity, and volatility of stock returns in Indonesian manufacturing firms. Also, the phenomenon of information technology usage can be one of the considerations for investors in order to discover what types of company's criterion that is appropriate to be included in their investment portfolio.
\end{abstract}

Keywords: investors' attention, returns, liquidity, volatility of stock returns

\section{INTRODUCTION}

The remarkably progress of information technology development has performed a significant alteration in the process of improving firm value. It can be observed from the high level of investors' awareness in regard to the brand and information provided by company (Da, Engleberg, and Gao, 2011; Bank, Larch, and George, 2011; Joseph, Wintoki, and Zhang, 2011). In addition to the seminal sources of information, internet has presumably operated an essential role not only in acquiring information, but also as a medium that can be utilised by companies either to publish a wide range of fundamental information or related news to attract potential investors. Such simplicity can help companies to reduce the cost of promotion which is done conventionally. Hereby, it is plausible for the company to release and post some information on internet as an essential consideration for attracting potential investors to put their funds into the capital market.

Husnan (1998) states that it is necessary for investors discovering information that relates to the dynamics of stock price changes. Knowledge of stock price changes is needed to anticipate the risks, particularly in the process of making decision regarding with the eligibility of a company's stock. In line with the theory of investment, virtually all elements of investment containing risk leads to uncertainty. Investors cannot certainly predict the level of returns that will be received. Given to this condition, investors incline to be faced on risks. One action that they need to do in minimising the risks is by collecting a number of information. Therefore, infor- 
mation retrieval over the internet is as well as an alternative way to obtain news and information about the prospective companies (Bank et al., 2011; Joseph et al., 2011; Scheitle, 2011).

According to Copeland (1976a; 1977b), the sequential arrival of information spreads unevenly. This leads the potential investors to be divided into two forms, namely the informed investors and the uninformed investors. The theory of asymmetry information notes that the differences arise because some investors are more aware on internal information and the corporate prospects than other investors (Brown and Hartzell, 2001; Tandelilin, 2001a; Hanafi, 2004).

We envisage that investors' awareness of information has implication to the achievement of potential investors, particularly in terms of stock trading activities that require a huge number of information. Heterogeneity of information among investors will eventually lead uninformed investors to have inferior performance in comparison to informed investors. This circumstance leads us to identify the causal relationship between the main variables, which consist of Google insight as the proxy of investors' attention, and several dependent variables comprise of returns, liquidity, and volatility of stock returns in Indonesia Stock Exchange (IDX). Herewith, the asymmetry information among investors will result in proof about how liquid the capital market in Indonesia. In this case, we make comparison in order to analyse how information retrieval conducted by investors influencing the performance of every company in the Indonesian manufacturing sector.

This paper adds to the burgeoning literature on investors' attention, returns, liquidity and volatility of stock returns. There have been many empirical studies that have examined the relationships between investor attention, stock returns, liquidity and the volatility of stock returns, such as Bank et al., (2011) examine the relationships between investor's attention measured by Google insight towards illiquidity. Da et al. (2011) point out the investor's attention quantified by internet search frequency and its effect towards Initial Public Offering (IPO) returns and price changes in the subsequent periods. Further, Ding and Hou (2011) note that investors' attention contributes significantly on liquidity measured by relative bid-ask spread. To date, only a few studies have investigated the phenomenon of internet usage towards returns, liquidity and volatility of stock returns in the condition of emerging capital market. Conducting such research is fascinating, especially investigating the condition of internet search activities and capital market in emerging country such as Indonesia. Deloitte Access Economics and Nielsen (2011), a representation of Google research institute in Asia Pacific, explains that the contribution of internet to the economy of Indonesia is around 1.6 per cent, or IDR 116 trillions. It is equivalent with 13 billion dollars of Indonesia Gross Domestic Product (GDP) in 2011 (Kompas, 2011). The results also report that although the rate of internet penetration in Indonesia is slightly low, the value of the internet economy in Indonesia has dominant proportion to GDP. As mentioned above, we show Figure 1 as an illustration of the growth rate of internet users in Indonesia since 1990 until 2010.

As shown in Figure 1, the population of internet users in Indonesia grows fast. The number of internet users in 1990's was only around 0.002 per cent of the total population at that time. The increasing number of users significantly rose since 2000 when it approximately reached about 9.8 per cent, or equals as many as 20.3 millions of the total population in the end of 2010 (BPS, 2010).

The development of information technology quickly creates a pattern of transition, notably the utilisation of analog technology systems to the adoption of digital technology systems. Consequently, the flow of incoming information is scattered and everyone who has interests may access the information directly. This is an interesting phenomenon that can be observed from economics point of view. Henceforth, this study aims to examine the effect of investors' attention towards returns, liquidity and volatility of stock returns, particularly in the manufacturing sector in Indonesia Stock Exchange (IDX) from 2009 to 2011 . 


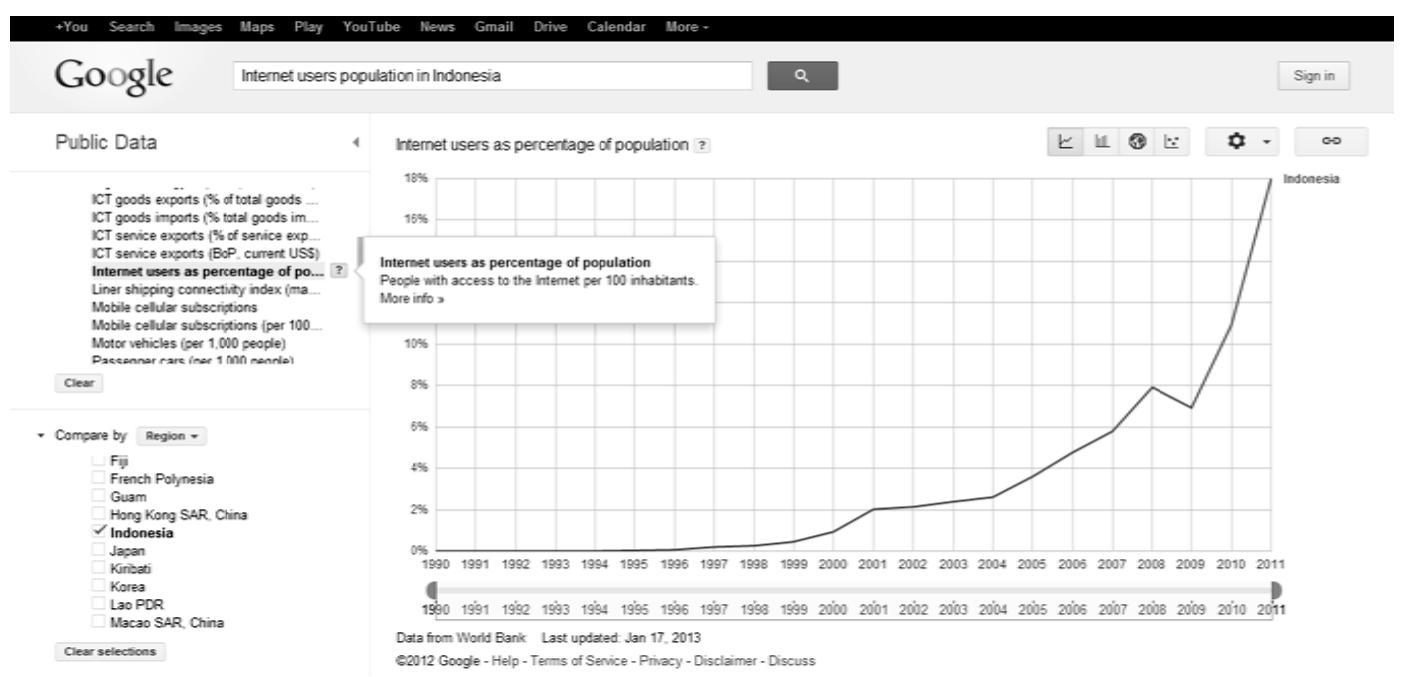

Sources: World Bank Data, accessible through Google Public Data and available at: (http://www.google.com/publicdata/explore?ds=d5bncppjof $8 f 9$ \#!ctype $=1 \&$ strail=false\&bcs $=\mathrm{d} \& n$

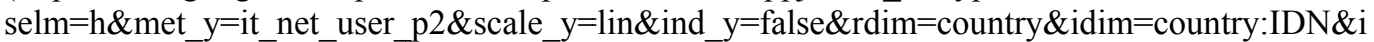
fdim $=$ country\&tstart $=\overline{63} 6811200000 \&$ tend $=1267963200000 \& h l=e n \_U S \& d l=e n \_U S \&$ ind $=$ false).

Figure 1. The Growth Rate of Internet Users in Indonesia from 1990 to 2010

\section{LITERATURE REVIEW AND HYPOTHESES DEVELOPMENT}

\section{Google Insight \& Internet Search Activity}

Google insight is one of Google features which basically aims to research the keywords and search trends in various regions of the world. Google insight has become a potential measurement tool that many social researchers use. Besides, it is due to its ability to quantify the phenomenon across place and time. The data obtained is then compared to the total search data recorded in Google servers around the world (Bank et al., 2011; Da et al., 2011; Joseph, 2011; Scheitle, 2011).

According to Da et al. (2011) and Bank et al. (2011), Google conducts a search word based on the taxonomy of the word entered by the seekers of information. Incoming data is then transformed by Google server. It will eliminate common trends in a popular search on the internet. As the samples used in this study, the categorization of words is based on company's names that are listed in Indonesia Stock Exchange (ticker symbols). Google insight then performs the filtration of search results. To anticipate the existence of bias in the data used, we distinguish the search filtrations that limited to the category of Finance, Business and Industries.

\section{Investors' Attention and Stock Returns}

According to asymmetry information theory, the quality of information owned by investors significantly influences the number of investment activities commenced by them. It is obviously seen that the level of information will bring an impact towards the stock performance in generating returns. Moreover, it has a correlation with the Efficient Market Hypothesis suggested by Fama and French (1995), who argue that information is necessary in attenuating the level of asymmetry between investors. Such information is derived from public information or private information. Several empirical studies have been conducted to examine the relationships between investors' attention, stock returns and trading volume. In this case, Tumarkin and Whitelaw (2001); Benbunan and Fich (2004); Fang and Peress (2009); Benzion et al., (2010); Koning et al., (2010) and Tetlock (2010) find that financial news has positive and significant contribution on returns and firm value. Furthermore, Bank et al., (2011); Da et al., (2011) and Joseph et al., (2011) employ a new alternative media, namely the Search Volume Index (SVI) that is obtained through Google insight as proxy in measuring investors' attention.

Based on the theoretical and empirical findings above, the low asymmetry of information 
will generate implications to the increase of volumes and demands of stocks. The high demands will cause the stock prices change upward and increase the returns higher. On the other hand, we do believe that in certain case, the increased recognition and familiarity of firm probably reduce the potential returns between investors. However, our hypothesis developed regarding to the previous studies and following similar approach that has been suggested by Gagnon and Karolyi, (2009) and Bank et al., (2011). As the logic explanation, the increase of stock returns tends to exist when the uninformed investors turned into informed investors. This circumstance particularly depicts the attenuating of asymmetry information between them. The information can be represented as financial ratios which are collected from the online publication of the firm's financial statements on internet, data relates to trading activity, the recent news in respect of firm action, and the other information which is collected and recorded by Google in a particular period. After collecting the appropriate data and information relating certain stocks, investors will design their portfolio of investment which consists of each stock that probably provides potential returns. Hereby, investors have determined the targeted stocks. As the real action, investors decide to purchase them all. Due to the lower of asymmetric information, many investors are competing in order to obtain the right stocks. Under this condition, the law of demand applies. The high demands of the same stocks compel the investors to compete each other. Here, the stockholders only sell their shares to other investors who want to pay for more expensive prices than the previous normal prices. Therefore, the attention from investors pushes the price getting higher in which this leads to the indication that those stocks are able to provide better returns for its stockholders. Also, we include several explanatory variables as suggested by Fama \& French (1995), namely price earnings ratio, age, size, and book-to-market equity ratio. These control variables is presumably essential in neutralising the interaction between the main variable. Given the number of previous studies and the stream of literatures, we consider that investors' attention contributes positively towards stock returns. Thus, we hypothesize if news and information are introduced to investors in the market (investor attention), then those investors will attempt to increase their ability to generate better returns.

\section{Investors' Attention and Liquidity}

The liquidity of stocks is measured by identifying the stock trading activity. The stock which is traded actively shows that it is favoured by investors. It means that the stocks are easily traded time by time. Several empirical studies have been conducted to examine the relationship between investors' attention and liquidity. In this case, research conducted by Kiymaz (2001) notes that the incoming information has influenced the level of returns and liquidity. A company which is rumoured in good news (positive rumours) tends to have better returns and trading volume than the other companies which are exposed to bad news (negative rumours). Meanwhile Tumarkin and Whitelaw (2001); Trueman et al., (2003); Benbunan and Fich (2004); Grullon et al., (2004); Chae, 2005; Gunduz and Hatemi (2005) find similar results. They point out that the change of stock prices reflects the new arrival of information into the market. Furthermore, we distinguish the types of information searches by identifying the keywords entered by investors. As illustrated by Ding and Hou (2011), users who type the ticker symbols of company justified as investor instead of the common users of internet.

The higher level of information retrieval on certain stocks will increase the quantity of informed investors. This circumstance will cause an increase in stock purchase. On one hand, it might probably negatively contributes on liquidity as shareholders may keep their shares due to higher future share prices. Meanwhile, considering the mainstream of the previous findings as mentioned above, such as findings showed by Gagnon and Karolyi (2009) who note that the dynamic relationships exists between incoming information and trading volume. Herewith, they point out that returns reversal with a given market or spillovers across markets that are associated with positive volume innovation stronger 
not only for larger firms, but also for those that receive more analyst coverage and investors interest. In addition, we utilise stock price, age, size, and book-to-market ratio as explanatory variables. As suggested by Kaniel et al., (2008), the implementation of control variables is useful in obtaining the efficient outputs and clarifying the relationship between main variables. We employ in this study the proposed hypothesis assuming that the increasing information contributes positively towards liquidity. Therefore, we build our second hypothesis with the notion, when there is information retrieval done by investors (investor attention), firms will experience higher trading volume.

\section{Investors' Attention and Volatility of Stock Returns}

Volatility of stock returns is a measure of the risk of investment. According to Tandelilin (2001a; 2010b), in order to quantify the total risk that is associated with the expected returns on an investment can be done by calculating the variance and standard deviation of investment. Moreover, asymmetry information theory states that informed investors do the transactions based on the information that they obtained before. Investors tend to make substantial transactions and influence the volatility as an impact of the arrival of information (Jones, 2003; Hartono, 2001, 2005; and Sari, 2004 in Sumiyana, 2007). These circumstances are in line to several empirical studies conducted by Copeland, (1976a; 1977b); Tumarkin and Whitelaw (2001); Kiymaz (2001); Werner and Murray, (2004); Kaniel et al., (2008); Bank et al., (2011); and Joseph et al., (2011). They note that the arrival of information positively relates to the volatility of stock returns. It is clarified by utilising the information as indicators and components of price formation. Previous study conducted by Bollerslev and Jubinski (1999) also suggests that in explaining the variation of volatility returns and its dynamics, information regarding the condition of company is needed. It is important for investors to collect some fundamental information such as return, age, size and book-tomarket. These variables are useful as consideration in selecting the best stock. Therefore, we use them as explanatory variables which are supposed to neutralise the interaction between the main variables.

Hereby, the search activities will cause the stock prices to be more volatile. The volatility tends to affect the pattern or trend of stock price movements. Therefore, the more information obtained by investor, the more it will drive the price towards the highest or lowest point. As the results, stocks incline to be more risky. Henceforth, investors will be faced on price fluctuations which can be observed according to the volatility of stock returns. Therefore, we design the third hypothesis as "if investors raise their attention on certain stocks, then it will increase the volatility of stock returns that is sought by them".

\section{METHODOLOGY}

\section{Data and Sample}

The process of data collection in measuring investors' attention is performed by Google insight. Also, the primary data of every company is provided by the official website of Indonesia Stock Exchange (www.idx.co.id), and Indonesia Capital Market Directory (ICMD CD-ROM). At first, the number of sample obtained in this research was 131 companies. However, we use purposive sampling method with the following criteria as pre requirements in data collection: (1) Companies that actively listed and traded in manufacturing sector, Indonesia Stock Exchange (IDX) during time period from 2009 to 2011, (2) Companies that have had the search data in Google insight and do not experience temporary suspension or termination during the period of observation, (3) Companies that have published their financial statements during the time period from 2009 to 2011. Therefore, in our analysis, we truncate the samples as many as 55 companies and determine 76 companies as the final samples.

The usage of the manufacturing sector as the sample is due to the stock trading activity that has grown significantly. In addition, there are three sectoral indices which consistently gener- 
ate better returns than Composite Index, namely Consumption, Basic Goods and Chemical, and Miscellaneous Industries Index (Rudiyanto, 2011).

\section{Measurement of Variables}

The measurements of research variables are listed in Table 1 as follows:

Table 1.

(Variable Definitions)

\begin{tabular}{|c|c|c|}
\hline No & Variables & Definition \\
\hline 1 & $\begin{array}{l}\text { Investors' } \\
\text { Attention (IA) }\end{array}$ & $\begin{array}{l}\text { Google insight is a tool that can be used in order to } \\
\text { quantify the flow of information retrieval done by } \\
\text { investors (investor attention). The search data of } \\
\text { company has experienced scaling and normalisation, } \\
\text { thus the available data is data ratio that ranges from } 0 \\
\text { as the lowest level of information retrieval, to } 100 \text { as } \\
\text { the highest level of information retrieval. It should be } \\
\text { noted that Google insight shows a tendency for users in } \\
\text { specific areas only, which is the value of internet search } \\
\text { terms are relative (not absolute). The data is available } \\
\text { at: } \\
\text { http://.google.com/insight/search/\# }\end{array}$ \\
\hline
\end{tabular}

2 Return (RET) Stock return is a gain that occurs at month $\mathrm{t}$, in which the difference between the recent stock price $\left(\mathrm{P}_{\mathrm{i}, \mathrm{t}}\right)$ and the past stock price $\left(\mathrm{P}_{\mathrm{it}-1}\right)$ then divide with the past stock price $\left(\mathrm{P}_{\mathrm{it}-1}\right)$. As mentioned above, returns used in this study are monthly returns.

3 Liquidity (TV) Measurement of trading activity is conducted by using natural logarithm (ln) of the number of stocks traded and then multiplied with the stock price.

4 Volatility of Volatility of stock returns is measured by calculating stock Return the standard deviation of every stock return.

(STDEV)

5 Market Market capitalization is used to measure the size of Capitalisation every firm which is calculated by multiplying the

(LNSIZE) number of logarithm natural of shares outstanding and the stock price.

6 Book-to- Book-to-Market equity ratio is a risk factor that need to Market Equity be considered by investors (Fama \& French 1995). (BM)

7 Price Earnings Price earnings ratio or closing share price at the end of Ratio (PER) respective financial statement period divided by earning per share.

8 Age (AGE) The age of company is necessary in order to identify the characteristic of samples. We count the age of company according the first time company had launched its Initial Public Offering (IPO) in Indonesia Stock Exchange.

9 Past Return Past return is a control variable that may affect the RET(-1) volatility of stock returns (Kaniel, et al., 2008).

The data of past return is obtained from the previous return in month $\mathrm{t}$. In particular, it is collected by using lag 1 or symbolised by RET(-1).

The form of data provided by Google is data ratio. The data is scaled by using percentage from 0 to 100 per cent. The data collected from Google is considered in the monthly aggregate information retrieval by using internet on certain stocks. Here, we use ticker symbol or the company's name as the keywords in collecting the time series data about the company. Also, we filter the data to the categorisation of finance, and business and industrial. The information retrieval is focused in the area of Indonesia. We conjecture that the rate of information retrieval is performed by uninformed investors.

$$
\begin{gathered}
R E T_{i, t} \frac{P_{i, t}-P_{i, t-1}}{P_{i, t-1}} \\
T V_{i t y}=\ln \left(V O_{i t y} x P_{i t y}\right. \\
\sqrt{\frac{\sum\left(X_{i}-\bar{X}\right)^{2}}{n-1}} \\
\text { LnSize }=\ln \left(P_{s} x S_{s}\right. \\
\mathrm{B} / \mathrm{M}=\frac{\text { Book Value }}{\text { Market Value }} \\
\text { PER }=\frac{\text { Market Price }}{\text { EPS }}
\end{gathered}
$$

Description: Variable definitions are collected from various sources. 


\section{Empirical Models}

The empirical models used in this study are panel data regression. Besides, we use E-views 6 as the statistical tool in determining what type of method that is appropriate to use in examining the hypotheses. Herewith, we use the Fixed Effect Model (FEM) as the final model. We determine the model by conducting the preliminary test to justify whether the Fixed Effect Model (FEM) is the most appropriate model than Pooled Least Square (PLS) and Random Effect Model (REM). Furthermore, to examine the hypotheses, we show the following three statistical models and including the explanatory variables as the control variables which are adopted from several researches in the previous studies:

\section{Statistical Model of Hypothesis 1}

$$
\begin{aligned}
R E T_{i, t}= & \alpha+\beta_{I} I A_{i, t}+\beta_{2} P E R_{i, t}+\beta_{3} A G E_{i, t}+ \\
& \beta_{4} L N S I Z E_{i, t}+\beta_{5} B M_{i, t}+\varepsilon
\end{aligned}
$$

Statistical model 1 is utilised to explain the influence of investors' attention (IA) towards returns (RET). We also employ several control variables that consist of PER, AGE, LNSIZE and BM. According to previous studies conducted by Bank et al. (2011), it is necessary to insert them in as additional factors of firm specifics that probably influence the interaction between the main variables. The main purpose of employing these variables is to clarify and neutralise the interaction between IA and RET. There are several seminal studies of the relation between investors' attention and stock returns. For instance, price is noteworthy variable in response to the returns changes. This fundamental information is essential for investors in deciding whether they will buy a specific stock that can be observed from this data. Further, price earnings ratio (PER) is one of fundamental information which is available in financial statements. Some fundamental researches believe that PER is an important measurement in quantifying the financial performance between prices and earnings. Ascertaining the PER value of a firm will lead the investors to discover the proper information, whether they get well- earned stocks or not. AGE can also be considered as essential information which is needed by investors. If a firm can survive in maintaining its operational activities in long time horizon, it reflects that the firm generates more stable profitability than the recent established firms. Given to the SIZE of company, we use it as the additional explanatory variable because of its comparability in separating the dimensions of firms. Besides, we note that size is necessary as the determinant of stock returns. Last, we employ book-to-market ratio (BM) in investigating whether the overvalued or undervalued securities is influencing the stock returns. However, we just put the data regarding to the effects of bookto-market without distinguishing them into the overvalued or undervalued securities.

For further explanation related to the equation 1 above, we denote $\mathrm{RET}_{\mathrm{i}, \mathrm{t}}$ as the monthly returns of every sample used from the Indonesian manufacturing sector. $\mathrm{PER}_{\mathrm{i}, \mathrm{t}}$ is the Price Earnings Ratio which is employed in viewing the individual stock market impact towards the firm's performance reflected by its EPS. $\mathrm{AGE}_{\mathrm{i}, \mathrm{t}}$ is the length of operational period time of companies. We count the age by calculating the first time companies had launched their Initial Public Offering (IPO) until the period of observation. LNSIZE $_{i, t}$ is market capitalisation which is calculated by multiplying the number of logarithm natural of shares outstanding and the stock prices. $\mathrm{BM}_{\mathrm{i}, \mathrm{t}}$ is book-to-market equity ratio which is used as risk factor that needs to be considered by investors. Based on the explanation of Fama and French (1995), the fact that the common factors in returns mirror common factors in earnings suggests that the market, size, and book-to-market factors in earning are the source of the corresponding factors in returns.

\section{Statistical Model of Hypothesis 2}

$$
\begin{aligned}
T V_{i, t}= & \alpha+\beta_{1} I A_{i, t}+\beta_{2} P R I C E_{i, t-1}+\beta_{3} A G E_{i, t}+ \\
& \beta_{4} L N S I Z E_{i, t}+\beta_{5} B M_{i, t}+\varepsilon
\end{aligned}
$$

Since the investors' attention is considered to have positive contribution in explaining the returns and liquidity, we employ the same explanatory variables and adding PRICE $E_{i, t}$ to in- 
vestigate the correlation and causal relationships of independent variables towards dependent variables. Hereby, $\mathrm{TV}_{\mathrm{i}, \mathrm{t}}$ denotes the trading activity which is measured by the natural logarithm of the number of stocks traded and multiplied with stock prices. $\mathrm{AGE}_{\mathrm{i}, \mathrm{t}}$ is the period of operational time of companies. We count the age by calculating the first time companies had launched their Initial Public Offering (IPO) in Indonesia Stock Exchange (IDX). With the same motive that has been exposed above, we employ AGE as explanatory variables, particularly to clarify the interaction between the independent variables towards dependent variables. Given to the operational time of company, we do consider that the older company tends experience simplicity in managing its trading activity. While others that have been operating in a short-time period, it is slightly difficult for them to increase their trading activity because the investors do not yet recognise these companies as well as the older company. Hereinafter, the use of LNSIZE $E_{i, t}$ has the same objective with the previous explanation. Trading volume inclines to be higher as the increase of the size of the company. We note the LNSIZE $_{i, t}$ as market capitalisation which is calculated by multiplying the number of logarithm natural of shares outstanding and the stock prices. $\mathrm{BM}_{\mathrm{i}, \mathrm{t}}$ is book-to-market equity ratio which is used as a risk factor that needs to be considered by investors.

\section{Statistical Model of Hypothesis 3}

$$
\begin{aligned}
\operatorname{STDEV}_{i, t}= & \alpha+\beta_{1} I A_{i, t}+\beta_{2} \operatorname{RET}_{i, t-1}+ \\
& \beta_{3} A G E_{i, t}+\beta_{4} L N \operatorname{SIZE}_{i, t}+ \\
& \beta_{5} B M_{i, t}+\varepsilon
\end{aligned}
$$

In the third model, we would like to investigate the influence of Investor's attention (IA) towards volatility of stock return (STDEV). We suppose that the fluctuation of returns in the model one is in line with volatility of stock returns. Herewith, STDEV $\mathrm{i}_{\mathrm{i}, \mathrm{t}}$ denotes the volatility of stock returns which is measured by computing standard deviation of individual stock returns. $\mathrm{RET}_{\mathrm{i}, \mathrm{t}}$ is monthly returns of every sample used in this research. As mentioned pre- viously, $\mathrm{AGE}_{\mathrm{i}, \mathrm{t}}$ is obtained by calculating the period when the first time companies launched their Initial Public Offering (IPO) in Indonesia Stock Exchange (IDX). LNSIZE $\mathrm{i}_{\mathrm{i}, \mathrm{t}}$ is market capitalisation which is calculated by multiplying the number of logarithm natural of shares outstanding and the stock prices. $\mathrm{BM}_{\mathrm{i}, \mathrm{t}}$ is book-tomarket equity ratio which is used as risk factor that needs to be considered by investors. Specifically, the application of book-to-market ratio within the equation 3 clearly relates to volatility returns. Logically, the stable book-to-market (BM) value can reduce the portfolio turnover for strategies that are based on BM ranking. Thus, in addition to providing at least as much returns dispersion as its competitors, BM may also reduce the number of transactions that is triggered by stocks moving in and out of the portfolio's buy range. The utilisation of four explanatory variables above is obviously considered for neutralising the interaction between the main variables. Besides, it can also note that each variable is supposed as determinant factors in explaining the variation of volatility returns in Indonesian manufacturing firms.

\section{Model Selection}

There are three techniques that can be examined in panel data regression, namely Pooled Least Squares (PLS), Fixed Effect Models (FEM) and Random Effect Models (REM). To determine which types of models will be used in estimating panel data, Chow test is performed. Chow test is utilised to compare between the Pooled Least Squares and Fixed Effects Models. Furthermore, Hausman test is performed to compare between Fixed Effect Model and Random Effect Models, (Gujarati, 1995; Baltagi, 2005).

Firstly, Chow test is done for each hypothesis testing. We find that data processing by using E-views shows the similar results, particularly regarding to the Chow test outputs in testing equation 1,2, and 3 . The outputs report that both $\mathrm{F}$ and Chi square value were significant ( $\mathrm{p}$-value 0.0000 is statistically significant at the $5 \%$ level). Therefore, we do not support the null hypothesis (H0) which recommends to use the 
pooled least square (PLS) approach, but support the alternative hypothesis (H1) that recommends to employ fixed effect model (FEM) for three equation model as mentioned above. Further, we conduct the Hausman test in determining whether the panel data regression will employ fixed effect model (FEM) or random effect model (REM). Hereby, we note the results of Hausman test for the three statistical models which show that cross section random probability for each equation models is 0.0000 . It means that Hausman test results suggest fixed effect model (FEM) as the final approach used in the panel data regression.

\section{FINDINGS AND DISCUSSION}

We begin the analysis by classifying the information of samples in summary statistics. Firstly, we truncate 55 from 131 companies. Therefore, it can be inferred that we only use 76 companies as the final samples that meet the criteria of purposive sampling method. Secondly, we separate the data of every company into selected variables (Panel A and Panel B). Then, data processing is done by utilising descriptive statistics feature in E-views 6. The descriptive data in Table 2 presents the detail of summary statistic samples as follows.

Table 2 provides plots for the time series of monthly descriptive data of the 76 selected companies. Specifically, Panel A displays the fundamental information in regard to the dependent variables, namely stock returns (RET), trading volume (TV), and volatility of stock returns (STDV). It is eminently seen that the average returns of manufacturing firms during the period from 2009 to 2011 is around $0.04 \%$, with minimum return is $-0.94 \%$ and maximum return is $3.30 \%$. In addition, the liquidity surrogated by trading volume (TV) depicts that the average trading volume is 14.98 millions with minimum trading activity 0 and the maximum monthly trading volume is 23.51 millions. Moreover, the average of volatility of stock returns (STDEV) is about $0.03 \%$ with minimum value $-0.03 \%$ and maximum value $0.41 \%$.

Investors' attention (IA) represented by Google insight in Panel B indicates the average of positive searching activity at $27 \%$. It means the level of information searches relative to the total searches on the available information on Google is $27 \%$. In addition, the minimum score

Table 2. Summary Statistics of Dependent and Independent Variables

\begin{tabular}{lrrrrrrrr}
\hline Variables & N & Mean & Median & Max & Min & $\begin{array}{c}\text { Std. } \\
\text { Dev }\end{array}$ & Observations & $\begin{array}{c}\text { Cross } \\
\text { sections }\end{array}$ \\
\hline \multicolumn{2}{l}{ Panel A: Dependent Variables } & & & & & & & \\
RET (\%) & 36 & 0.04 & 0 & 3.30 & -0.94 & 0.19 & 2,736 & 76 \\
TV & 36 & 14.98 & 15.71 & 23.51 & 0 & 5.11 & 2,736 & 76 \\
STDEV & 36 & 0.03 & 0.02 & 0.41 & -0.03 & 0.02 & 2,736 & 76 \\
Panel B: Independent Variables & & & & & & \\
IA (\%) & 36 & 27 & 21 & 100 & 0 & 28.07 & 2,736 & 76 \\
PER & 36 & 11.5 & 8.4 & 800 & -875 & 50.66 & 2,736 & 76 \\
PRICE & 36 & 8,167 & 750 & 369,000 & 25 & 3,017 & 2,736 & 76 \\
RET(-1) & 36 & 0.04 & 0 & 3.30 & -0.94 & 0.19 & 2,736 & 76 \\
AGE & 36 & 17.7 & 18 & 32 & 3 & 5.25 & 2,736 & 76 \\
LNSIZE & 36 & 27.61 & 27.35 & 33.33 & 23.13 & 2.06 & 2,736 & 76 \\
BM & 36 & 1.24 & 0.93 & 9.72 & 0.02 & 1.25 & 2,736 & 76 \\
\hline
\end{tabular}

Description: The descriptive statistics data in Table 2 are obtained by utilising formula in Table 1. This Table describes the summary statistics comprise of mean, minimum, maximum and standard deviation of each variable. Our sampling period starts on January 2009 and ends on December 2011. Our sample is drawn from the Indonesian manufacturing sector the combination of consumption index, basic goods index and chemical and miscellaneous industries index) which consists of three-year time series data and 76 cross-listed stocks available at Indonesia Capital Market Directory (ICMD CD-ROM) during the observation periods from 2009 to 2011. 
of searches activity is $0 \%$ and the maximum score is $100 \%$. The other explanatory variables are illustrated in Panel B. These variables consist of PER, PRICE, RET(-1), AGE, LNSIZE \& BM. The main purpose for including these variables is to clarify and neutralise the interaction between the main variables. Given to this condition, we decide to employ explanatory variable as firm's specifics, in which the average value for Price Earnings Ratio (PER) is 11.5 with the minimum value -875 and the maximum value at 800. Further, the average PRICE is around IDR 8,167 per share, with the minimum PRICE at IDR 25 and maximum at IDR 369,000. The previous return (RET(-1)) shows the similar number with the returns showed at Panel A. This happens because we use the lag of returns at month $t$ as a determinant of the recent returns of certain stocks. Our samples show that the average AGE of every company listed in manufacturing sector is around 17.7 years. The youngest company (minimum age of sample) has been operating for three years. Meanwhile, the oldest (Maximum age of sample) has been operating for 32 years since the first time it launched the Initial Public Offering (IPO). The summary statistics also describe the market capitalisation (LNSIZE) in which the average of LNSIZE is 27.61, with the minimum value 23.13 and the maximum 33.33.
The mean of book-to-market ratio (BM) is about 1.24 with the minimum value around 0.02 and the maximum value at 9.72 . We assume that all of these control variables are useful in clarifying and neutralising the characteristics of samples. Therefore, we combine the similar control variables suggested by Kaniel et al., (2008), Bank et al, (2011), and Doskeland and Hvide, (2011).

\section{The Analysis of Hypothesis 1}

In the next step, we analyse the hypothesis testing on statistical model one. The result for the examination of investors' attention (IA) towards stock returns (RET) is shown in Table 3 below.

The statistical output shown in Table 3 displays that investor attention (IA) contributes positively and significantly $(p<0.05)$ towards returns (RET). This finding is obviously consistent with the previous research conducted by Fang and Peress, (2009), Da et al., (2011), Joseph et al., (2011) and Bank et al., (2011) who report that the increase of information retrieval performed by investors is an effort in truncating the level of asymmetry information. As the results, this circumstance will rise the opportunity to earn higher returns. We notice that our

Table 3. The Results of Hypothesis Testing 1

\begin{tabular}{|c|c|c|c|c|}
\hline \multicolumn{5}{|c|}{ Dependent Variable: RET } \\
\hline Variables & $\beta$ & t-Statistic & Prob. & \\
\hline$\overline{\mathrm{C}}$ & 0.0295 & 0.6754 & 0.4994 & \\
\hline IA & 0.0002 & $2.1059 * *$ & 0.0353 & \\
\hline PER & -0.0001 & $-2.4021 * *$ & 0.0164 & \\
\hline AGE & -0.0005 & -0.9226 & 0.3563 & \\
\hline LNSIZE & -0.0011 & -0.7195 & 0.4719 & \\
\hline $\mathrm{BM}$ & -0.0075 & $-2.9881 * *$ & 0.0028 & \\
\hline R-squared & 0.0074 & Durbin-Watson stat & & 2.0320 \\
\hline Adjusted R-squared & 0.0056 & & & \\
\hline F-statistic & 4.0875 & & & \\
\hline Prob(F-statistic) & 0.0010 & & & \\
\hline
\end{tabular}

Description: According to the statistical output that is conducted by using fixed effect model (FEM), we find that the value of coefficient determination or $\mathrm{R}^{2}$ is relatively small $(0.007431)$ or equal as $0.74 \%$. It means that only $0.74 \%$ of the variation occurs in the dependent variable (Returns) can be explained by independent variables (IA, PER, AGE, LNSIZE, BM). Thus, the independent variables used in this study cannot fully explain the dependent variable as well.

*** (Statistically significant at the 1\% level)

** (Statistically significant at the 5\% level)

* (Statistically significant at the 10\% level) 
result is similar to the issue pointed out by Doskeland and Hvide (2011), in which the asymmetry information tends to exist between informed and uninformed investors. Herewith, the existence of informed investor is commonly represented by the presence of institutional investors. Otherwise, the uninformed investors derived from individual investors. Given to this condition, we assume that work experiences and the accumulated knowledge about pattern and information regarding to certain stocks are beneficial for individual investors in diminishing the gap between them.

In line with the result obtained in Table 3, Table 4 describes the influence of investors' attention (IA) towards stock returns (RET) that has been controlled by several types of control variables. We use these controlling variables in order to clarify the interaction of main variables. Given the causality of relationships, we need to examine the magnitude of every explanatory variable in possessing the robust results.

Outputs in Table 4 are supposed to present the magnitude of every independent variable towards dependent variable. Hereby, the regression coefficient of variable investor's attention (IA) is slightly small. However, the statistical analysis output indicates that IA still has significant effects $(p<0.05)$ on stock returns (RET). This finding supports the previous studies reported by Grullon et al (2004), Benzion et al., (2010), Koning et al., (2010) and Bank et al., (2011) who state that the increasing level of investors' attention inclines to rise the stock returns. Also, the role of every explanatory variable is shown according to the signal derived from the coefficient variable. We point out that price earnings ratio (PER) and book-to-market ratio (BM) negatively and significantly contribute towards stock returns. As mentioned in the literature review, fundamental information in regard to firm performance is obviously needed by investor. PER and BM are clearly the fundamental data which can be gathered from financial statements. However, these two explanatory variables show negative and significant contribution on stock returns. This is due to the rational pricing. As stated by Fama and French (1995), in a rational market, short-term variation in profitability should have little effect on stock price, and book-to-market value should be associated with long-term differences in profitability. Moreover, the return responses to the book-tomarket factor in fundamental do not consistently reproduce the strong and intuitively pleasing

Table 4. The Influence of Investor's Attention Towards Stock Returns After Being Controlled by Additional Control Variables

\begin{tabular}{lrrrrr}
\hline \multicolumn{1}{c}{$\begin{array}{c}\text { Independent } \\
\text { Variables }\end{array}$} & \multicolumn{1}{c}{1} & \multicolumn{1}{c}{3} & \multicolumn{1}{c}{4} & \multicolumn{1}{c}{5} \\
\hline IA & 0.0002 & 0.0002 & 0.0002 & 0.0002 & 0.0002 \\
& $(2.2178)^{* *}$ & $(2,3519)^{* *}$ & $(2.4153)^{* *}$ & $(2.3700)^{* *}$ & $(2.1059)^{* *}$ \\
PER & & -0.0001 & -0.0001 & -0.0001 & -0.0001 \\
& & $(2.2328)^{* *}$ & $(2.1960)^{* *}$ & $(2.2312)^{* *}$ & $(2.4021)^{* *}$ \\
AGE & & -0.0005 & -0.0006 & -0.0005 \\
& & & $(-1.0166)$ & $(-1.1550)$ & $(-0.9226)$ \\
LNSIZE & & & 0.0010 & -0.0011 \\
& & & & $(0.7295)$ & $(-0.7195)$ \\
BM & & & & & -0.0075 \\
& & & & & \\
$\mathrm{R}^{2}$ & 0.0017 & 0.0036 & 0.0039 & 0.0041 & 0.0074 \\
\hline
\end{tabular}

Description: t-statistics are shown in parentheses.

*** (Statistically significant at the $1 \%$ level)

** (Statistically significant at the 5\% level)

* (Statistically significant at the $10 \%$ level) 
patterns observed when returns and fundamentals are examined separately. On the other hand, we find that AGE and LNSIZE show insignificant contribution towards return. According to literature review, size and age also relate to profitability. In this case, our tests do not support the interaction of size and age in explaining the causal relationship between these explanatory variables and returns. The explanation about this condition is related to the patterns in the relationships between age (AGE), size (LNSIZE) and returns (RET) are not as strong as expected. Fama and French (1995) also note the relationship between these factors, in which given the similarity between the way stock returns load on the common factors in returns and the way earnings load on similar common factors in earning.

\section{The Analysis of Hypothesis 2}

The finding of statistical model two that examines the influence of investors' attention (IA) towards liquidity (TV) is shown in Table 5 below.

The statistical outputs in Table 5 describe that investors' attention (IA) has shown positive and significant effect $(p<0.01)$ towards liquidity. This finding confirms the previous studies noted by Kiymaz (2001), Tumarkin and Whitelaw (2001), Trueman et al., (2003), and Benbunan and Fich (2004) who point out that by increasing the number of information retrieval, it will contribute to the increase of liquidity. Furthermore, these results also support the research reported by Da et al., (2011) and Bank et al., (2011) who show that expanding the flow of information will increase the trading volume. In line with the finding of Gagnon and Karolyi (2009), market participants keep a close eye on trading volume (TV) because it is presumed to reflect the dynamic interplay between informed and uninformed traders who interact with each other in the pursuit of their own trading strategies and, ultimately, set market clearing prices. Informed agents trade rationally for both informational and noninformational reasons, and the degree of asymmetry information alters the volume-returns dynamics. Particularly, returns generated by noninformational risks sharing trades tend to reverse themselves, while those generated by speculative trades tend to continue themselves. Herewith, the utilisation of trading volume as a surrogate indicator in measuring liquidity is viewed by many as the critical piece of information that signals where price will go next.

Table 5. The Results of Hypothesis Testing 2

\begin{tabular}{lcrcc}
\hline \multicolumn{1}{c}{ Dependent Variable: TV } & \multicolumn{3}{c}{} \\
\hline \multicolumn{1}{c}{ Variable } & $\beta$ & \multicolumn{1}{c}{ t-Statistic } & Prob. & \\
\hline C & $-65,706$ & $-12,9645$ & 0,0000 & \\
IA & 0,0103 & $3,9947^{* * *}$ & 0,0001 & \\
PRICE & $-1,2643$ & $-2,5514^{* *}$ & 0,0108 & \\
AGE & 0,3357 & $3,4118^{* * *}$ & 0,0007 & \\
LNSIZE & 2,7009 & $13,1523^{* * *}$ & 0,0000 & \\
BM & $-0,0351$ & $-0,3323$ & 0,7397 & \\
& & & & 0,9006 \\
R-squared & 0,6508 & Durbin-Watson stat & & \\
Adjusted R-squared & 0,6402 & & & \\
F-statistic & 61,854 & & & \\
Prob(F-statistic) & 0,0000 & & & \\
\hline
\end{tabular}

Description: According to the statistical output by using Fixed effect model, the value of coefficient determination or $\mathrm{R}^{2}$ in the second hypothesis testing is about 0.6508 or $65.08 \%$. It means that approximately $65.08 \%$ of the variation occurs in the dependent variable (TV) can be explained by the influence of independent variables (IA, PRICE, AGE, LNSIZE, BM). While the other $34.2 \%$ can be explained by entering additional factors outside the research model.

*** (Statistically significant at the $1 \%$ level)

** (Statistically significant at the $5 \%$ level)

* (Statistically significant at the $10 \%$ level) 
In order to get the comprehensive estimation outputs, we check the magnitude of the main variable (IA) by adding several explanatory variables. Table 6 displays results for included variables and explanatory power of the model. The magnitude of investors' attention (IA) towards liquidity (TV) after being controlled by several controlling variables is obviously observed as follows.

It is important to note that the magnitude of variable investors' attention (IA) indicates positive and significant $(p<0.01)$ impact towards liquidity (TV). The magnitude of this variable remains the stable value and positive sign during the process of adding several new explanatory variables. It denotes that the effect of investors' attention (IA) towards liquidity (TV) is significantly positive even though we use several control variables in neutralising the interaction between the main variables. Further, PRICE inclines to show the positive effect towards liquidity. However, this condition does not stand much longer, where at the certain point PRICE tends to show the negative effect towards liquidity. It means that the increase of price will attract investors in gaining better returns and this will lead to the increase of liquidity. Moreover, the higher price will cause the stocks become less liquid. This happens because the stock price is going to be more expensive and unaffordable for individual investors to purchase. Then, the others explanatory variables, namely AGE and LNSIZE have shown the positive and significant contribution towards liquidity. Thus the results reflect that age and size are related to the liquidity. Hereby we assume that age and size are considerable for investors as the risk factors in avoiding the illiquidity. Latest, the magnitude of book-to-market ratio (BM) shows a negative sign, but insignificantly contributes to liquidity.

\section{The Analysis of Hypothesis 3}

Statistical model three is addressed to examine the influence of investors' attention (IA) towards the volatility of stock returns (STDEV). The results can be observed in Table 7 as follows.

Recall that in the analysis of hypothesis 1 , we find one tailed causal relationship between investors' attention (IA) and stock returns (RET). Therefore, the statistical output shown in Table 7 suggests that investors' attention (IA) contributes positively and significantly $(p<0.01)$ towards the volatility of stock returns (STDEV).

Table 6. The Influence of Investor's Attention on Liquidity After Being Controlled by Additional Control Variables

\begin{tabular}{|c|c|c|c|c|c|}
\hline $\begin{array}{l}\text { Independent } \\
\text { Variables }\end{array}$ & 1 & 2 & 3 & 4 & 5 \\
\hline IA & $\begin{array}{c}0.0298 \\
(11.1520)^{* * *}\end{array}$ & $\begin{array}{c}0.0286 \\
(10.6641)^{* * *}\end{array}$ & $\begin{array}{l}0.0139 \\
(5.1173)^{* * *}\end{array}$ & $\begin{array}{l}0.0103 \\
(3.9993)^{* * *}\end{array}$ & $\begin{array}{l}0.0103 \\
(3.9947)^{* * *}\end{array}$ \\
\hline PRICE & & $\begin{array}{l}2.05141 \\
(3.9727)^{* *}\end{array}$ & $\begin{array}{c}2.5008 \\
(0.4959)\end{array}$ & $\begin{array}{l}-1.2968 \\
(-2.6702)^{* * *}\end{array}$ & $\begin{array}{l}-1.2643 \\
(-2.5514)^{* * *}\end{array}$ \\
\hline AGE & & & $\begin{array}{c}1.3588 \\
(16.4123)^{* * *}\end{array}$ & $\begin{array}{l}0.3325 \\
(3.3962)^{* * *}\end{array}$ & $\begin{array}{l}0.3357 \\
(3.4118)^{* * *}\end{array}$ \\
\hline LNSIZE & & & & $\begin{array}{c}2.7449 \\
(17.4939)^{* * *}\end{array}$ & $\begin{array}{c}2.7009 \\
(13.1523)^{* * *}\end{array}$ \\
\hline $\mathrm{BM}$ & & & & & $\begin{array}{c}-0.0351 \\
(-0.3323)\end{array}$ \\
\hline $\mathrm{R}^{2}$ & 0.5685 & 0.5710 & 0.6105 & 0.6507 & 0.6508 \\
\hline
\end{tabular}

Description: t-statistics are shown in parentheses.

*** (Statistically significant at the 1\% level)

** (Statistically significant at the 5\% level)

* (Statistically significant at the 10\% level) 
Table 7. The Results of Hypothesis Testing 3

\begin{tabular}{lcrrl}
\hline \multicolumn{2}{c}{ Dependent Variable: STDEV } & & & \\
\hline \multicolumn{1}{c}{ Variables } & $\beta$ & t-Statistic & Prob. & \\
\hline C & 0.0342 & 1.4327 & 0.1521 & \\
IA & 3.4988 & $2.6585^{* * *}$ & 0.0079 & \\
RET(-1) & -0.0205 & $-8.4500^{* * *}$ & 0.0000 & \\
AGE & -0.0018 & $-3.6655^{* * *}$ & 0.0003 & \\
LNSIZE & 0.0010 & 1.0141 & 0.3106 & \\
BM & -0.0005 & -0.7475 & 0.4548 & \\
& 0.2312 & Durbin-Watson stat & \\
R-squared & 0.2073 & & & \\
Adjusted R-squared & 9.6961 & & & \\
F-statistic & 0.0000 & & & \\
Prob(F-statistic) & & & & \\
\hline
\end{tabular}

Description: Based on the statistical outputs by using Fixed effects model (FEM), we obtain that the value of coefficient determination or $\mathrm{R}^{2}$ is relatively small $(0.2312)$ or $23.12 \%$. This result means that only about $23.12 \%$ of the variation occurs in the dependent variable (STDEV) can be explained by independent variables (IA, RET(-1), AGE, LNSIZE, BM). The rest of influence that is $76.88 \%$ can be only explained by the factors or other variables outside the research model.

$* * *$ (Statistically significant at the $1 \%$ level)

** (Statistically significant at the $5 \%$ level)

* (Statistically significant at the $10 \%$ level)

This finding indicates that the increase of search information undertaken by investors inclines to rise the total risk (Tandelilin 2001a). This finding is also consistent with the theory of asymmetry information, in which investors who gain better information, tend to make more transactions. The high intensity of these transactions has increased the returns and its volatility as the result of information arrival. Though that there has probably been a dramatic increase in returns in the recent past, in the months immediately prior to the incoming information, there may still be considerable uncertainty in the market regarding whether the returns can be maintained at their new level of returns. In this circumstance, investors will attempt to utilise any data and information available to reduce the uncertainty and risks. This finding confirms the research conducted by Fama et al., (1969) where the adjustment of stock prices to new information related to the uncertainty itself. Specifically, in this case, Fama et al., (1969) employ the information about dividend announcement as the triggered factor in responding the incoming information towards the adjustment of stock price movement. Little bit different from the finding shown by Fama et al. (1969), information retrieval is supposed to influence the volatility of stock returns at the same time of the increasing of price and returns. Herewith, we assume that the volatility exists because the involvement of uninformed investors who turned into informed investors already.

Finally, we test for the significance and magnitude of investors' attention (IA) towards the volatility of stock returns (STDEV) that is controlled by the additional explanatory variables as follows.

Based on information in Table 8, investors' attention (IA) shows significant effect $(p<0.01)$ towards the volatility of stock returns (STDEV), even though we have added several control variables in order to clarify and neutralise the correlations and relationships of every variable. It has been prevalently noted that the variance or the volatility of returns differs considerably from stock to stock. However, hereby we note that the signs of the regression coefficient of investors' attention (IA) after being controlled by explanatory variables towards volatility returns (STDEV) are consistent with those predicted by our model in equation 3. Further, the regression coefficient of past return (RET(-1)) shows the persistent negative signs towards volatility of stock returns. This means that risk measured by using volatility returns (STDEV) higher as the past return gets bigger. The rational explanation 
Table 8. The Influence of Investor's Attention Towards Volatility of Stock Returns After Being Controlled by Additional Control Variables

\begin{tabular}{lrrrrr}
\hline $\begin{array}{l}\text { Independent } \\
\text { Variables }\end{array}$ & \multicolumn{1}{c}{2} & \multicolumn{2}{c}{3} & \multicolumn{1}{c}{4} & \multicolumn{1}{c}{5} \\
\hline IA & 2.3519 & 2.3122 & 3.6105 & 3.4988 & 3.4988 \\
& $(1.8634)^{*}$ & $(1.8378)^{*}$ & $(2.7718)^{*}$ & $(2.6931)^{* * *}$ & $(2.6585)^{* * *}$ \\
RET(-1) & -0.0218 & -0.0209 & -0.0204 & -0.0205 \\
& & $(-9.0934)^{* * *}$ & $(-8.6584)^{* * *}$ & $(-8.4516)^{* * *}$ & $(-8.4500)^{* * *}$ \\
AGE & & -0.0013 & -0.0019 & -0.0018 \\
& & & $(-3.7396)^{* * *}$ & $(-3.8265)^{* * *}$ & $(-3.6655)^{* * *}$ \\
LNSIZE & & & 0.0014 & 0.0010 \\
& & & & $(1.7810)^{*}$ & $(1.0141)$ \\
BM & & & & -0.0005 \\
& & & & & \\
$\mathrm{R}^{2}$ & 0.1862 & 0.2235 & 0.2294 & 0.2305 & $0.0 .7475)$ \\
\hline
\end{tabular}

Description: $t$-statistics are shown in parentheses.

$* * *$ (Statistically significant at the 1\% level)

** (Statistically significant at the 5\% level)

* (Statistically significant at the 10\% level)

regarding to this condition is because virtually all informed investors in the Indonesian manufacturing sector incline to hold their stock without selling it when the price getting higher. It denotes that the motive of investors is gaining long-term profit by conducting long-term investment. Hence, even though the potential returns gained from the price movements are getting higher, investors will not suddenly sell their stocks in gaining short-term profit. Further, age (AGE) and book-to-market ratio (BM) show negative contribution on volatility returns. However, the regression coefficients of these factors are not statistically significant. We discover that the volatility of stock returns lower as the AGE and BM get higher. Then, the last explanatory variable is LNSIZE in which contributes positively on volatility returns. We suppose that the number of market capitalisation relates to the volatility of stock returns, in which the outstanding shares relate to the possibility of higher trading volume which persistently influence the risks of investment. These findings are supported by Bollerslev and Jubinski, (1999) who note the behaviour of equity trading volume and volatility for the individual firms composing Standard \& Poor's composite index. Specifically, they find that the aggregate "news"-arrival process possesses long-memory characteristics, which is caused by the behaviour of investors who tend to gain better returns based on the information that can alter either the components of liquidity or volatility.

\section{Discussion}

Following previous studies in developing market, we consider to commence the research in the context of emerging market. It is important to understand though, that in the context of an emerging economy the range of variables that might be employed for the purpose of seeking information retrieval through internet on the dynamic relationships between stock returns, liquidity and volatility of stock returns is somewhat limited. Information in respect of Indonesian manufacturing sector is scarce and of dubious reliability. The phenomenon of using digital information technology is particularly shown a tremendous effect towards the economy activity, either in developing or emerging country. Herewith, the literature review posits a variety of variables that could potentially form the basis for effective measurement in explaining 
the sequential information retrieval. Therefore, to facilitate a brief analysis of those most pertinent to the exposure of stock returns, liquidity, and volatility returns, we employ Google insight which provides information as a surrogated indicator in quantifying the sequential information retrieval and representing the investors' attention in making portfolio investment. In particular, we find that investor's attention (IA) surrogated by Google insight is essentially useful in order to clarify and investigate the phenomenon of information arrival in Indonesian manufacturing sector. This incoming information is necessarily important not only for companies in the Indonesia Stock Exchange (IDX), but also investors.

Notwithstanding the existence of numerous studies on investors' attention on one hand, returns, liquidity and volatility returns on the other, no prior study has sufficiently integrated these three issues in emerging market arena. Our results show that investors' attention represented by Google insight has capability in explaining the variation of returns, liquidity and volatility of stock returns. Further, we also utilise six control variables in convincing the value and interaction between variables used in this study. However, the obtained results are not entirely clear-cut, where it shows that the value of main variable is not strong enough in order to explain the variation of dependent variables. On the other hand, several control variables such as AGE and PRICE have shown stronger magnitude than the investors' attention itself. It becomes clear when we find that the values of $R^{2}$ and adjusted $R^{2}$ in the three models are relatively small, particularly the value of $R^{2}$ in statistical model 1 and statistical model 3 . These circumstances triggered by the arrival of information, which is not entering the market simultaneously and evenly. In these asymmetry information models, new information that reaches the market is not disseminated to all participants simultaneously, but to one trader at a time. This reason relates to the findings reported by Gunduz and Hatemi (2005), who state that the sequential information hypothesis supports several intermediate equilibria, such that only when all traders have received the new information is final market equilibrium estab- lished. Such condition is happening in emerging market, which the sample used in their study obtained from five emerging capital market namely Czech Republic, Hungary, Poland, Russia, and Turkey.

In response to these findings, it has become increasingly important for Indonesia stock exchange to investigate the influence of investors' attention represented by information retrieval on the internet towards stock returns, liquidity and volatility returns. In particular, Indonesia Stock Exchange (IDX) is considered as an emerging capital market. Different from in more developed economies, the importance of incoming information has been well established. For instance, NASDAQ and German stock exchange incline to experience the diffusion of information rapidly. Almost all of investors have the equal opportunity in gathering information. It can be observed from the relatively high score of coefficient determination $\left(\mathrm{R}^{2}\right)$ in explaining the variation of returns (Da et al., 2011; Bank et al, 2011). Henceforth, information arrival in emerging market is conjectured as transitory effect. Further, Dimplfl and Jank, (2012) find the similar results, which the small values of $\mathrm{R}^{2}$ are compelled by two problems. Firstly, the search volume generated by Google is less precise because of the statistical method employed in developing the search volume. Secondly, for some search traffic of several samples are too low. These conditions result in missing value of the number of searches. Due to the high correlation of these search terms, the other search terms or ticker symbols do not add further information to the search we use. Therefore, the values of coefficient determination $\left(\mathrm{R}^{2}\right)$ of three statistical models are relatively small. While, these results are understandable, they are proving a positive impediment at the present time to use information provided by internet in obtaining better returns.

Our findings have significant implications for research on emerging market's stock returns as well as for market participants and policymakers. Firstly we provide further validity and confirmation regarding to the dynamics investors' attention concerning on an information 
retrieval by using internet, liquidity surrogated by trading volume, and risk represented by volatility of stock returns. These relationships proposed by a variety of heterogeneous trading model out of sample. Secondly, by presenting a confirmation relates to the role of internet as a valuable tool for conveying information about future returns, our study lends additional reliance to the school of thought arguing that the information retrieval conducted by investors is an alternative way in order to attenuate the asymmetry information between informed and uninformed investors. Further, policymakers may also use this finding in attributing several new policies that is particularly useful in truncating the number of thin trading in Indonesia stock exchange.

\section{CONCLUSIONS}

This paper analysed the influence of investors' attention (IA) towards returns (RET), liquidity (TV) and volatility of stock returns (STDEV). The findings show that investors' attention positively and significantly $(p<0.05)$ contributes to stock returns (RET). This result is consistent with research conducted by Fang and Peress, (2009), Da et al., (2011), Joseph et al., (2011) and Bank et al., (2011). They reveal that the increase of information retrieval will improve the opportunity to earn higher returns. Furthermore, investors' attention (IA) contributes positively and significantly $(p<0.01)$ on liquidity (TV). This result confirms the previous studies reported by Kiymaz (2001), Tumarkin and Whitelaw (2001), Trueman et al., (2003), Benbunan and Fich (2004), and Gunduz and Hatemi (2005) in which an increasing number of information retrieval will increase the liquidity. In addition, investors' attention (IA) also has performed positive and significant impact $(p<$ 0.01 ) towards volatility of stock returns (STDEV). The findings in this study are also consistent with the theory of asymmetry information, in which investors who gain better information, tend to make more transactions. As the results, investors will push the intensity of returns alterations which lead to the high volatility returns.

\section{Limitation and Implication}

Our sample is drawn from the three subsectoral indices which form the Indonesian manufacturing sector, namely consumption index, basic goods and chemical index and miscellaneous industries index. We acknowledge that it is perhaps disappointing that our analysis is unable to distinguish further exploration between the sequential information as the accurate indicator in measuring the investors' attention, and instead the empirical results show that all these variables are considered of very similar importance by the majority of Indonesia stock exchange (IDX). Given to this circumstance, hereby, we note several limitations. First, nonsynchronous trading may be a contributing factor in the case of Indonesian manufacturing sector. Infrequent trading in this industry could produce some predictability in stock returns if new information is not instantly embedded in stock prices and/or a high percentage of stocks remain inactive. As all stocks do not trade simultaneously, there will be some outdated stock prices whenever a stock index is compiled. This condition is similar to the outputs reported by Gunduz and Hatemi, (2005) in which Hungary and Poland are denoted as emerging market. Herewith, we suppose that every stock listed in emerging capital market such as Indonesia tends to be more susceptible in respond to the incoming information. Second, since the model cannot control the firm specifics as the effect of differences in fundamental information such as size, price earnings ratio, and book-to-market ratio between these and previous studies, such as those in the developing market, bias may supposed to exist. Third, the characteristic of firms are not grouped as shown in the previous studies. Here, we do not build a portfolio to classify the samples according to their classification in size (small, medium and big), book-to-market ratio (high, medium, low) and price within high medium and low rank.

The empirical findings support the general conjectures that information does tell us something about future price movement and returns across stocks. The analysis also notes that the actual information retrieval over the internet is 
one of the alternative methods in diminishing the asymmetry information between informed and uninformed investors. Also, we point out that investors' attention shows dynamic relationship with stock returns, liquidity and volatility of stock returns. Empirical analysis obtained from these models for short-horizon returns, liquidity and volatility returns that seem encompass the variety that actually exist in Indonesia stock exchange (IDX). There are still a number of unanswered questions. However, the focus of analysis on panel data regression is rationalized for its convenience.

\section{REFERENCES}

Baltagi, B. H. (2005). Econometric Analysis of Data Panel $3^{\text {rd }}$ Edition. England. John Wiley \& Sons.

Bank, M., Larch, M., \& George,, P. (2011). Google Search Volume and Its Influence on Illiquidity and Returns of German Stocks. Financial Market Portofolio Management (25). Pp 239-264.

Benbunan, R., \& Fich, E. (2004). Effects of Web Traffic Announcement of Firm Value. International Journal of Electric Commerce Summer (8). Pp. 161-182.

Benzion, U., Tavor, T., \& Yagil, J. (2010). Information Technology and Its Impact on Stock Returns and Trading Volume. International Journal of Finance and Economics (15). Pp. 247-262.

Bollerslev, T., \& Jubinski, D. (1999). Equity Trading Volume and Volatility: Latent Information Arrivals and Common LongRun Dependencies. Journal of Business \& Economics Statistics. (17). Pp. 9-21.

BPS 'Central Bureau of Statistic'. (2010). www.BPS.go.id. Accessed on 24 February 2012. 11:30. PM.

Brown, W. G., \& Hartzell, C. J. (2001). Market Reaction to Public Information: The Atypical Case of The Boston Celtics. Journal of Financials Economics (60). Pp.333-370.

Chae. J (2005). Trading Volume Asymetry Information and Timing Information. Journal of Finance (1). Pp. 413-442
Copeland, T. E. (1976a). A Model of Asset Trading Under The Asumption of Sequential Information Arrival. American Economic Review (4). Pp. 1149-1168.

Copeland, T. E. (1977b). A Probability Model of Asset Pricing. Journal of Financial and Quantitative Analysis (4). Pp. 563-578.

Da, Z., Engleberg, J., \& Gao, P. (2011). In Search of Attention. The Journal of Finance (66). Pp 1461-1499

Delloitte Access Economics. (2011). The Connected Archipelago, The Role of Internet in Indonesia's Economic Development. Delloit. Sydney, NSW. Australia.

Dimplfl, T., \& Jank, S. (2012). Can Internet Search Queries Help to Predict Stock Market Volatility. University of Tübingen Working Papers in Economics and Finance (18). Pp. 1-32.

Ding, R., \& Hou, W. (2011). Retail Investor's Attention and Stock Liquidity. Working Paper Series, SSRN. Can be accessed in: http://papers.ssrn.com/sol3/papers.cfm?abstr act $i d=1786762$. Accessed on 27 February, 2011. 09:35. AM.

Doskeland, M. T., \&. Hvide, H. K. (2011). Do Individual Investors Have Asymmetric Information Based on Work Experienced? The Journal of Finance (3). Pp. 1011-1041.

Fama, E. F., Fisher, L., Jensen, MC., \& Roll, R. (1969). The Adjustment of Stock to New Information. International Economic Review (10). Pp.1-21.

Fama, E.F.,\& French, R. F. (1995). Size and Book to-Market Factors in Earning and Returns. Journal of Finance (1). Pp. 131155.

Fang, L., \& Peress, J. (2009). Media Coverage and the Cross Section of Stock Returns and Bonds. Journal of Financial Economic (33). Pp 2113-2127.

Gagnon, L., \& Karolyi, G. A. (2009). Information, Trading Volume, and International Stock Return Comovements: Evidence from Cross-Listed Stocks. Journal of Financial and Quantitative Analysis. (44). Pp. 953986.

Google. (2012). Insight for Search. Available at (http://.google.com/insight/search/\#). 
Grullon, G., Kanatas, G., Weston, J.P. (2004). Advertising, Breadth of Ownership and Liquidity. Review of Financial Study (17). Pp. 439-461.

Gujarati, N. D. (1995). Basic Econometrics, Third Edition. New York: MacGraw-Hill.

Gunduz, L \& Hatemi, J. (2005). Stock Price and Volume Relation in Emerging Market. Emerging Market Finance and Trade (41). Pp. 29-44.

Hanafi, M. (2004). Manajemen Keuangan. BPFE, Yogyakarta.

Husnan, S. (1998). Dasar-Dasar Teori Portofolio dan Analisis Investasi Edisi Ketiga. UPP AMP YKPN. Yogyakarta.

Joseph, K., Wintoki, B. M., \& Zhang, Z. (2011). Forecasting Abnormal Return and Trading Volume Using Investor Sentiment: Evidence From Online Search. International Journal of Forecasting (27). Pp. 1-21.

Kaniel, R., Saar, Gideon., \& Titman, S. (2008). Individual Investor Trading and Stock Return. Journal of Finance (1). Pp. 273310.

Kiymaz, H. (2001). The Effect of Stocks Market Rumors on Stock Prices: Evidence From Emerging Market. Journal of Multinational Financial Management (11). Pp.105-115.

Kompas: Purwanto, D., \& Hidayat S. W. (2011). http://tekno.kompas.com/read/2011/12/13/1 6152949/Inilah.Manfaat.Internet.bagi.kono mi.Indonesia. Accessed on Tuesday 13 December 2011.

Koning, M., Mertens, G., \& Roosenboom, P. (2010). The Impact of Media Attention on The Use of Alternative Earning Measure. Journal of Accounting, Finance and Business Study (3). Pp. 258-288.

Rudiyanto. (2011). Prospect of Sectoral Mutual Funds. KONTAN, 2 May 2011.
Scheitle, P. C. (2011). Google Insight for Search: A Note Evaluating The Use of Search Engine Data in Social Research. Social Science Quarterly (92). Pp.287-295.

Sumiyana. (2007). Noise Atau Kedatangan Informasi: Sebuah Fenomena Spesifik Perilaku Harga Saham Di Pasar Modal Indonesia. Jurnal Ekonomi dan Bisnis Indonesia (3). Pp.292-318.

Tandelilin, E. (2001a). Analisis Investasi dan Manajemen Portofolio. Yogyakarta. BPFE.

Tandelilin, E. (2010b). Portofolio dan Investasi "Teori dan Aplikasinya". Yogyakarta. Kanisius.

Tetlock, C. P. (2010). Does Public Financial News Resolve Asymetry Information? The Review of Financial Studies (23). Pp. 35203556.

Trueman, B., Wong, M.H., \& Zhang, X. (2003). Anomalous Stock Return Around Internet Firms Earning Announcements. Journal of Accounting and Economics (34). Pp. 249271.

Turmakin, R., \& Whitelaw, R.F. (2001). News or Noise? Internet Message Board Activity and Stock Prices. Financial Analyst Journal (57). Pp. 41-51.

Werner, A., \& Murray, F. Z. (2004). Is All That Talk Just Noise? The Information Content of Internet Stock Message Boards. Journal of Finance (59). Pp. 1259-1294.

World Bank Data \& Google Public Data. (2011) Internet users as percentage of population in Indonesia. Available at: (http://www.google.com/publicdata/explore ?ds $=\mathrm{d} 5$ bncppjof $8 \mathrm{f} 9$ \#! ctype $=1 \&$ strail $=$ false $\mathrm{bcs}=\mathrm{d} \& n s e l m=h \& m e t \_y=i t \_n e t \_u s e r \_p 2 \& s$ cale_y=lin\&ind_y=false\&rdim $=$ country\&id $\mathrm{m}=$ country:IDN\&ifdim $=$ country\&tstart $=636$ $811200000 \&$ tend $=1267963200000 \& \mathrm{hl}=\mathrm{enU}$ S\&dl=en_US\&ind=false). Accessed on 23 February, 2011. 10:43. AM. 